\title{
Uji Ketahanan Planlet Anggrek Bulan (Phalaenopsis amabilis (L.) Bl.) Hasil Seleksi dengan Asam Salisilat Terhadap Fusarium oxysporum Secara In Vitro
}

\section{Induced Resistance of Moon Orchid Plantlet (Phalaenopsis amabilis (L.) Bl.) as Result of The In Vitro Salicylic Acid Selection Toward to Fusarium oxysporum}

\section{Ria Aulia Noviantia, Endang Nurcahyani*, dan Martha Lulus Lande}

Jurusan Biologi - FMIPA Universitas Lampung - Bandar Lampung, Indonesia

Jl. Prof. Dr. Soemantri Brojonegoro No. 1, Bandar Lampung, Indonesia 35145

E-mail : riaaulia74@gmail.com

\begin{abstract}
Phalaenopsis amabilis cultivated have many constraints such as the appearance of fusarium wilt disease caused by Fusarium oxysporum. Plantlet P.amabilis which resistant to F. Oxysporum was selected in the solid Vacin and Went $(V W)$ medium was added with salicylic acid at concentrations of $65 \mathrm{ppm}, 75 \mathrm{ppm}$, and $85 \mathrm{ppm}$, compared with controls $(0 \mathrm{ppm})$. The goals of the research were to study and determine of: 1) The SA concentration of planlet P. amabilis selection tolerant; 2) The proper concentration of AS during in vitro selection for suppressing the Fo. The research was carried out in December 2015 to February 2016 in the Botany Laboratory (in vitro research room), Departement of Biology, Faculty of MIPA, Lampung University. The result showed that: 1) The SA tolerant concentration for plantlet selection with P. amabilis was between 65 ppm - 85 ppm. 2) The 85 ppm of SA was effective for suppressing the Fo compared to 65 ppm and 75 ppm.
\end{abstract}

Keywords: Phalaenopsis amabilis, salicylic acid, Fusarium oxysporum, In vitro, Resistance.

Diterima : 30 Maret 2016, Disetujui : 18 Juli 2017

\section{PENDAHULUAN}

Anggrek bulan (Phalaenopsis amabilis (L.) Bl.) adalah salah satu tanaman anggrek yang banyak diminati oleh berbagai kalangan karena keindahan bentuk dan warna bunganya (Purwati, 2012). Anggrek bulan juga merupakan salah satu bunga nasional Indonesia. Indonesia memiliki tiga bunga nasional yang ditetapkan melalui Keputusan Presiden Nomor 4/1993, yaitu bunga melati (Jasminum sambac L.) sebagai puspa bangsa, bunga padma raksasa (Rafflesia arnoldii R. Br.) sebagai puspa langka, dan bunga anggrek bulan (Phalaenopsis amabilis) sebagai puspa pesona (Puspitaningtyas \& Mursidawati, 2010).

Tanaman anggrek dalam pertumbuhannya mendapatkan gangguan yang dihadapi seperti timbulnya penyakit dari jamur patogen, bakteri, ataupun virus yang menyerang bagian-bagian pada tubuh tanaman anggrek (Djatnika, 2012). Beberapa penyakit pada tanaman anggrek yang disebabkan oleh jamur, bakteri, dan virus adalah busuk hitam, busuk akar, layu fusarium, busuk lunak, bercak daun, busuk daun, Cymbidium mosaic, dan bercak bercincin. Penyakit layu fusarium merupakan salah satu kendala dalam budidaya tanaman anggrek bulan yang disebabkan oleh jamur Fusarium oxysporum (Fo), dan dapat menyerang akar yang terluka (Pandjaitan, 2005). 
Salah satu cara alternatif pengendalian penyakit yang efektif dan aman terhadap lingkungan adalah menggunakan varietas yang tahan atau resisten (Nurcahyani, 2013). Penggunaan varietas unggul yang tahan terhadap $F o$ dengan daya hasil tinggi merupakan cara alternatif pengendalian penyakit dan tidak menimbulkan dampak negatif seperti penggunaan pestisida (Ambar et al., 2003). Pengembangan kultivar tahan Fo tersebut dapat dilakukan dengan metode seleksi in vitro yaitu mengkulturkan eksplan berupa organ atau jaringan pada medium yang mengandung asam salisilat dengan konsentrasi selektif (Suryanti et al.,2009).

Asam salisilat merupakan signal penting dalam ketahanan tanaman, digunakan sebagai senyawa pengimbas ketahanan tanaman pisang terhadap penyakit layu Fusarium (Suryanti et al., 2009). Asam salisilat di gunakan pada tanaman sebagai reaksi terhadap infeksi patogen, dan digunakan sebagai racun murni pada penyakit layu Fusarium. Mekanisme ketahanan tanaman terhadap penyakit dapat berupa ketahanan secara fisik maupun kimia. Salah satu bentuk ketahanan secara kimia adalah asam salisilat (Corina et al., 2009 dalam Sujatmiko et al., 2012; Rebecca et al., 2007 dalam Sujatmiko et al., 2012).

\section{METODE PENELITIAN}

Penelitian ini dilaksanakan pada bulan Desember 2015 sampai dengan bulan Februari 2016 di Laboratorium Botani (ruang penelitian in vitro), Jurusan Biologi, Fakultas Matematika dan Ilmu Pengetahuan Alam, Universitas Lampung. Penelitian dilaksanakan dalam rancangan acak lengkap dengan 4 perlakuan dan 5 ulangan. Perlakuan adalah penambahan asam salisilat ke dalam medium VW (Vacin and Went) dengan konsentrasi 0 ppm (kontrol), 65 ppm, 75 ppm, dan 85 ppm.

Persiapan medium tanam dan seleksi. Medium yang digunakan adalah Vacin and Went (VW) padat dengan penambahan Zat Pengatur Tumbuh (ZPT) Benzine Amino Purine (BAP). Setelah medium dicairkan, kemudian medium disterilisasi selama 15 menit. Medium VW yang sudah disterilkan kemudian ditambah asam salisilat (AS) dengan konsentrasi 0 ppm (kontrol), 65 ppm, 75 ppm, dan 85 ppm.

Penanaman planlet dalam medium seleksi asam salisilat. Eksplan yang digunakan berupa planlet steril. Planlet-planlet dari botol kultur dikeluarkan dengan scalpel steril dan satu-persatu diletakkan di atas cawan petri berdiameter $10 \mathrm{~cm}$, kemudian planlet dipilah satu-satu, setelah itu ditanam pada masing-masing botol kultur yang berisi medium perlakuan yang telah ditentukan. Masing-masing konsentrasi dilakukan 5 kali ulangan dan setiap ulangan terdiri dari 2 eksplan Phalaenopsis amabilis dalam setiap botol kultur.

Inokulasi Fo Pada Planlet Anggrek Bulan. Inokulasi monospora dilakukan menurut teknik Hadisutrisno (1995) sebagai berikut. Inokulasi Fo dilakukan secara langsung pada planlet anggrek bulan dalam botol kultur. Mikrokonidium jamur Fo dengan kerapatan spora 1,7 x $10^{4}$ per $\mathrm{mL}$ diteteskan pada planlet 1-2 tetes. Kemudian diinkubasikan pada suhu kamar $\left(25{ }^{\circ} \mathrm{C}\right)$ selama 24 jam. Pengamatan dilakukan selama 3 minggu dengan mengamati dan menghitung jumlah daun yang menunjukan gejala layu dengan indeks kelayuan menurut He et al. (2002) seperti di sajikan dalam Tabel 1.

Intensitas Penyakit (IP) dihitung dengan rumus :

$$
\begin{aligned}
& \mathrm{IP}=\frac{\Sigma(\mathrm{nxv})}{\mathrm{N} \times \mathrm{Z}} \times 100 \% \\
& \text { Keterangan : } \\
& \text { IP } \quad \text { Intensitas Penyakit } \\
& \mathrm{n} \quad \text { : Jumlah tanaman pada skor } \mathrm{v} \\
& \mathrm{V} \quad \text { : Nilai skor tertentu } \\
& \mathrm{N} \quad \text { : Jumlah tanaman yang diuji } \\
& \mathrm{Z} \quad \text { : Nilai skor tertinggi }
\end{aligned}
$$


Tabel 1. Indeks kelayuan menurut He et al. (2002)

\begin{tabular}{ll}
\hline Skor & Keterangan \\
\hline 0 & Tidak ada gejala kuning (layu atau tanaman sehat) \\
1 & 1-2 daun kuning (layu) \\
2 & 3 daun kuning (layu) \\
3 & 4 daun kuning (layu) \\
4 & Lebih dari 4 daun kuning (layu) atau tanaman mati \\
\hline
\end{tabular}

Tingkat ketahanan tanaman ditentukan berdasarkan skoring dengan mengacu pada ketentuan Wibowo (2002) seperti ditunjukkan dalam Tabel 2 sebagai berikut.

T abel 2. Tingkat Ketahanan tanaman menurut Wibowo (2002)

\begin{tabular}{ll}
\multicolumn{1}{c}{ IP $(\%)$} & Kriteria Ketahanan \\
\hline$\leq 25$ & Tahan \\
$25<$ IP $\leq 50$ & Moderat \\
$>50$ atau mati & Rentan \\
\hline
\end{tabular}

Keterangan : IP = Intensitas Penyakit

\section{HASIL DAN PEMBAHASAN}

Hasil seleksi planlet anggrek bulan berdasarkan persentase jumlah planlet hidup dengan berbagai konsentrasi AS disajikan pada Tabel 3.

Tabel 3. Persentase jumlah planlet hidup hasil seleksi dengan asam salisilat

\begin{tabular}{ccccc}
\hline $\begin{array}{c}\text { Konsentrasi Asam salisilat } \\
\text { (ppm) }\end{array}$ & \multicolumn{5}{c}{ Persentase jumlah planlet hidup pada minggu (\%) } \\
\cline { 2 - 5 } & I & II & III & IV \\
\hline 0 & 100 & 100 & 100 & 100 \\
65 & 100 & 100 & 100 & 100 \\
75 & 100 & 100 & 100 & 100 \\
85 & 100 & 100 & 100 & 80 \\
\hline
\end{tabular}

Tabel 3 menunjukkan bahwa pada minggu I, II, dan III pada konsentrasi 65, 75, 85 ppm, dan kontrol persentase jumlah planlet hidup mencapai 100\%. Pada planlet anggrek bulan yang diperlakukan dengan konsentrasi 65, 75, 85 ppm pada minggu ke-IV tidak mengalami kematian, sedangkan pada konsentrasi 85 ppm mengalami kematian 20\%. Menurut Purwati et al. (2007) menyatakan bahwa keberhasilan seleksi in vitro dipengaruhi oleh ketersediaan metode regenerasi planlet dalam jumlah banyak dan keefektifan agen penyeleksi yang digunakan. Asam salisilat (AS) dapat digunakan sebagai agen penyeleksi dalam seleksi in vitro untuk memperoleh varian yang tahan terhadap Fusarium oxysporum. Hasil seleksi planlet anggrek bulan berdasarkan persentase visualisasi planlet dengan berbagai konsentrasi AS disajikan pada Tabel 4.

Jumlah planlet pada konsentrasi AS 0-85 ppm pada minggu I menunjukkan 100\% hidup dan secara visual semuanya hijau. Mulai minggu II planlet yang ditanam pada medium AS 75-85 ppm menunjukkan adanya perubahan secara visual berwarna hijau dengan bagian tertentu cokelat atau browning dengan persentase paling tinggi sebesar 20\%. Planlet yang ditanam pada konsentrasi AS 85 ppm secara visual menunjukkan browning pada minggu IV dan mengalami kematian sebesar $20 \%$.

Hasil secara visualisasi menunjukkan bahwa planlet yang semula berwarna hijau kemudian menjadi hijau cokelat pada bagian tertentu, dan browning setelah diberi perlakuan dengan AS. Planlet yang tahan AS, browning hanya terjadi pada bagian ujung daun, sedangkan planlet yang tidak tahan AS akan mengalami browning yang cepat meluas ke seluruh bagian planlet. 
Tabel 4. Persentase dan visualisasi planlet hasil seleksi dengan berbagai konsentrasi asam salisilat

Konsentrasi asam salisilat (ppm)

Persentase dan visualisasi planlet pada minggu (\%)

\begin{tabular}{lllllll} 
& \multicolumn{1}{c}{ I } & \multicolumn{1}{c}{ II } & \multicolumn{1}{c}{ III } & IV \\
\hline 0 & H $: 100$ & H $: 100$ & H $: 100$ & H & 100 \\
65 & H $: 100$ & H $: 100$ & H $: 100$ & H 100 \\
75 & H $: 100$ & H $: 80$ & H $: 60$ & H $: 50$ \\
& HC: 0 & HC: 20 & HC: 40 & HC: 50 \\
& H $: 100$ & H $: 80$ & H $: 70$ & H $: 60$ \\
& HC: 0 & HC: 20 & HC: 30 & HC: 20 \\
& & & & C : 20 \\
\hline
\end{tabular}

Keterangan: $\mathrm{H}=\mathrm{Hijau} ; \mathrm{HC}=$ Hijau Cokelat $; \mathrm{C}=$ Cokelat atau browning

Berdasar pengamatan terhadap planlet anggrek bulan hasil pengimbasan yang diuji terlihat bahwa pada hari ke-4 setelah inokulasi muncul gejala daun layu pada kontrol. Gejala daun layu juga muncul pada 65 ppm. Sedangkan pada perlakuan 75 ppm terlihat gejala layu pada hari ke-8. Gejala tersebut merupakan karakteristik layu Fusarium (Nurcahyani, 2013), sehingga dapat dilakukan perhitungan persentase daun layu atau kuning (Tabel $5)$.

Tabel 5. Persentase daun layu atau kuning pada setiap perlakuan asam salisilat

\begin{tabular}{ccccccc}
\hline \multirow{2}{*}{ Perlakuan } & \multicolumn{6}{c}{ Persentase daun layu atau kuning pada hari pengamatan ke: } \\
\cline { 2 - 7 } & 0 & 4 & 8 & 12 & 16 & 20 \\
\hline Kontrol & 0 & 33.33 & 66.67 & 66.67 & 66.67 & 100.00 \\
$65 \mathrm{ppm}$ & 0 & 33.33 & 33.33 & 66.67 & 66.67 & 66.67 \\
$75 \mathrm{ppm}$ & 0 & 0 & 33.33 & 33.33 & 33.33 & 33.33 \\
$85 \mathrm{ppm}$ & 0 & 0 & 0 & 0 & 0 & 0 \\
\hline
\end{tabular}

Berdasarkan Tabel 5 diketahui gejala daun layu atau kuning yang muncul pada hari ke-4 setelah inokulasi menunjukkan bahwa persentase daun layu atau kuning pada kontrol dan perlakuan 65 ppm telah mencapai ratarata $33.33 \%$. Sedangkan perlakuan 75 ppm baru menunjukkan gejala daun layu atau kuning pada hari ke-8 dengan persentase $33.33 \%$ pada kontrol meningkat menjadi $66.67 \%$. Peningkatan persentase daun layu atau kuning juga terjadi pada perlakuan 65 ppm pada hari ke-12 menjadi 66.67\%. Pada perlakuan 85 ppm tidak menunjukkan adanya daun layu atau kuning.

Berdasarkan skoring terhadap gejala daun layu atau kuning yang muncul maka dapat diketahui persentase intensitas penyakit dan kriteria ketahanan dari masing-masing perlakuan (Tabel 6).

Tabel 6. Intensitas penyakit hasil uji ketahanan dan tingkat ketahanan anggrek bulan pada setiap perlakuan asam salisilat

\begin{tabular}{|c|c|c|c|c|c|c|c|c|c|c|}
\hline \multirow{3}{*}{ Perlakuan } & \multicolumn{10}{|c|}{ Hari Pengamatan } \\
\hline & \multicolumn{2}{|r|}{4} & \multicolumn{2}{|r|}{8} & \multicolumn{2}{|c|}{12} & \multicolumn{2}{|r|}{16} & \multicolumn{2}{|r|}{20} \\
\hline & $\begin{array}{l}\text { IP } \\
(\%)\end{array}$ & $\begin{array}{c}\text { Kriteria } \\
\text { Ketahanan }\end{array}$ & $\begin{array}{l}\text { IP } \\
(\%)\end{array}$ & $\begin{array}{c}\text { Kriteria } \\
\text { Ketahanan }\end{array}$ & $\begin{array}{l}\text { IP } \\
(\%)\end{array}$ & $\begin{array}{c}\text { Kriteria } \\
\text { Ketahanan }\end{array}$ & $\begin{array}{l}\text { IP } \\
(\%)\end{array}$ & $\begin{array}{c}\text { Kriteria } \\
\text { Ketahanan }\end{array}$ & $\begin{array}{l}\text { IP } \\
(\%)\end{array}$ & $\begin{array}{c}\text { Kriteria } \\
\text { Ketahanan }\end{array}$ \\
\hline Kontrol & 33,33 & Moderat & 66,67 & Rentan & 66,67 & Rentan & 66,67 & Rentan & 100 & Rentan \\
\hline $65 \mathrm{ppm}$ & 33,33 & Moderat & 33,33 & Moderat & 66,67 & Rentan & 66,67 & Rentan & 66,67 & Rentan \\
\hline $75 \mathrm{ppm}$ & 0 & Tahan & 33,33 & Moderat & 33,33 & Moderat & 33,33 & Moderat & 33,33 & Moderat \\
\hline $85 \mathrm{ppm}$ & 0 & Tahan & 0 & Tahan & 0 & Tahan & 0 & Tahan & 0 & Tahan \\
\hline
\end{tabular}

Keterangan : IP= Intensitas Penyakit 
Berdasarkan Tabel 6 dapat diketahui bahwa pada hari ke-20, intensitas penyakit tertinggi ditunjukkan oleh kontrol (100\%), dan perlakuan 65 ppm memiliki 66,67\% sehingga dinyatakan rentan terhadap layu Fusarium,

sedangkan perlakuan 75 ppm memiliki intensitas penyakit 33,33\% sehingga kriteria ketahanannya adalah moderat. Pada perlakuan 85 ppm intensitas penyakit kurang dari $25 \%$ sehingga kriteria ketahanannya adalah tahan.

Berdasarkan data intensitas penyakit dan kategori ketahanannya, dapat diketahui bahwa perlakuan AS 85 ppm mampu mengimbas ketahanan yang paling baik, dapat menekan intensitas pnyakit kurang dari $25 \%$ sehingga kriteria menjadi tahan. Hal ini menunjukkan bahwa AS mampu mengimbas ketahanan planlet anggrek bulan terhadap penyakit layu Fusarium.

Hasil penelitian ini sesuai dengan pendapat Suryanti et al (2009) yang menyatakan bahwa bibit pisang (Musa sp.) hasil pengimbasan terhadap asam salisilat memiliki ketahanan yang lebih tinggi dari pada kontrol dengan seleksi in vitro. Hasil penelitian ini juga mendukung pernyataan Agrios (2005) yang menyatakan bahwa ekspresi dari pengimbasan ketahanan adalah dengan menurunnya intensitas penyakit. Pada penelitian Nurcahyani (2013) menyatakan bahwa AF mampu mengimbas ketahanan planlet vanili terhadap penyakit layu Fusarium.

\section{KESIMPULAN}

Kisaran konsentrasi asam salisilat toleran untuk seleksi planlet anggrek bulan secara in vitro adalah 65-85 ppm. Secara in vitro penekanan perkembangan jamur $F$. oxysporum menggunakan seleksi asam salisilat pada konsentrasi 85 ppm lebih efektif dibandingkan konsentrasi 65 dan 75 ppm. Konsentrasi asam salisilat 85 ppm mampu mengimbas ketahanan yang paling baik, sehingga mampu menekan intensitas penyakit hingga $0 \%$.

\section{DAFTAR PUSTAKA}

Agrios, G.N. 2005. Plant Pathology, 5th ed. Elsevier Academic Press. California.

Ambar, A.A., Tjokrosoedarmo, A.H., Pusposendjojo, N., dan Wibowo, A. 2003. Patogenesis Isolat Fusarium Oxysporum F.Sp. Lycopersici dari 4 lokasi pada Tomat. Agrosains. XVI(2).

Djatnika, I. 2012. Seleksi Bakteri Antagonis Untuk Mengendalikan Layu Fusarium pada Tanaman Phalaenopsis. J. Hort 22 (3): 276-284.

Hadisutrisno, B. 1995. Pengendalian Hayati Penyakit Busuk Batang Vanili. Buletin Azolla. 2: 15-21.

He CY, Hsiang T, \& Wolyn DJ. 2002. Induction of Systemic Disease Resistance and Pathogen Defence Responses in Asparagus officinalis Inoculated with Pathogenic Strains of Fusarium oxysporum. Plant Pathology 51:225-230.

Nurcahyani, E., I. Sumardi, B. Hadisutrisno, dan E. Suharyanto. 2012. Penekanan Perkembangan Penyakit Busuk Batang Vanili (Fusarium oxysporum f. sp. vanillae) Melalui Seleksi Asam Fusarat Secara In Vitro. Jurnal Hama dan Penyakit Tumbuhan Tropika. Terakreditasi SK No. 110/DIKTI/Kep/2009. ISSN: 1411-7525. Vol. 12 /No. 1: 12-22.

Panjaitan, E. 2005. Respons Pertumbuhan Tanaman Anggrek (Dendrobium sp.) Terhadap Pemberian BAP dan NAA Secara In Vitro. Jurnal Penelitian Bidang Ilmu Pertanian. Vol.3. No. 3. Pp: 4551 .

Purwati, P. 2012. Pengaruh Macam Media Dalam Keberhasilan Aklimatisasi Anggrek Phalaenopsis Amabilis (Anggrek Bulan). Program Studi Hortikultura Jurusan Budidaya Tanaman Pangan Politeknik Negeri Lampung. 
Purwati, R.D., U.S. Budi, dan Sudarsono. 2007. Penggunaan asam fusarat dalam seleksi in vitro untuk resistensi abaka terhadap Fusarium oxysporum f.sp. cubense. Jurnal Littri. 13(2): 64-72.

Puspitaningtyas, D.M. \& Mursidawati.2010. Koleksi Anggrek Kebun Raya Bogor. UPT Balai Pengembangan Kebun Raya-LIPI. Bogor.1(2).

Sujatmiko, B, Sulistyaningsih E., dan Murti, H.R. 2012. Studi Ketahanan Melon (Cucumis melo L) Terhadap Layu Fusarium Secara In-Vitro dan Kaitannya dengan Asam Salisilat. Ilmu Pertanian Vol. 15: 1-18.

Suryanti, Chinta, Y.D., dan Sumardiyono,D. 2009. Pengimbasan Ketahanan Pisang Terhadap Penyakit Layu Fusarium dengan Asam Salisilat In Vitro. Jurnal Perlindungan Tanaman Indonesia 15 (2)pp: 90-95.

Wibowo, A. 2002. Pengendalian penyakit layu fusarium pada pisang dengan menggunakan isolat non patogenik Fusarium sp. Jurnal Fitopatologi Indonesia.6:65-70. 